Journal of Medical and Health Studies (JMHS)

ISSN: 2710-1452

DOI: $10.32996 / j m h s$

Journal Homepage: www.al-kindipublisher.com/index.php/ jmhs

\title{
Customer Satisfaction During the Covid-19 Pandemic Period at Private Clinic X Surabaya
}

\section{Laura Wulandari 8 iD. \\ Department of Epidemiology, Faculty of Public Health, Universitas Airlangga, Airlangga Health Care Center 2 Campus C Mulyorejo, Surabaya, East Java 60115, Indonesia}

$\triangle$ Corresponding Author: Laura Wulandari, E-mail: laura.wulandari-2018@fkm.unair.ac.id

\author{
ARTICLE INFORMATION \\ Received: March 17, 2021 \\ Accepted: May 11, 2021 \\ Volume: 2 \\ Issue: 1 \\ DOI: $10.32996 /$ jmhs.2021.2.1.2
}

\section{KEYWORDS}

Patient, Satisfaction, Survey

\section{ABSTRACT}

In an effort to provide public services, there are still many shortcomings when viewed from a quality perspective. It is still far from what the community expects. If this condition is not responded to, it will cause a bad image. During a pandemic period, the health system maintains a balance between meeting the needs for handling a pandemic and fulfilling essential health services. With a health protocol that must be carried out in order to break the chain of the spread of COVID-19, it is necessary to make technical adjustments to health services carried out by the FKTP. This, of course, can affect the quality of service which can also affect the satisfaction felt by patients. This study is an analytic observational study using non-probability techniques with an accidental sampling method with a sample of 200 people who are patients of clinic $X$ in Surabaya and review patient satisfaction documents in the previous year. The variables studied were reliability, responsiveness, assurance, empathy and tangible aspects. The satisfaction received by clink $X$ patients during the COVID-19 pandemic in 2020 was 3.60. In 2019, Clinic X received 3.85 satisfaction. The decline in the average score of patient satisfaction was at least in the assurance aspect $(0.21)$, while the other four aspects experienced a decrease (0.26). There is a need for improvement efforts according to the current conditions of the COVID-19 pandemic to improve service and customer satisfaction at clinic $\mathrm{X}$ in Surabaya.

\section{Introduction}

Health is a human right and one of the elements of welfare that the aspirations of the Indonesian people must realize. Everyone has the right to live in physical and spiritual prosperity, to have a place to live and to have a good and healthy living environment, and the right to obtain health services ${ }^{2}$. This has been stated in Law number 40 of 2004 concerning the National Health Insurance System (SJSN), which is then regulated in Article 19 paragraph 1 of the SJSN Law. Further regulations are then written in Law number 24 of 2011 concerning the Social Security Administration (BPJS), a change from Health Insurance (ASKES).

In the BPJS era, the First Level Health Facility (FKTP) became the spearhead of health services and became the center for BPJS membership. As the first line of health services, the FKTP must be strengthened and committed to providing optimal service. The clinic is a health service center that organizes individual health services and provides primary and specialized medical services, which can provide safe, quality services by prioritizing patients' best interests by professional standards, service standards, and standard operational procedures ${ }^{3}$.

According to the 2014 Regulation of the Minister of State Apparatus Empowerment and Bureaucratic Reform (Permenpan RB), there are still many deficiencies in providing public services. From a quality perspective, it is still far from what people expect. This
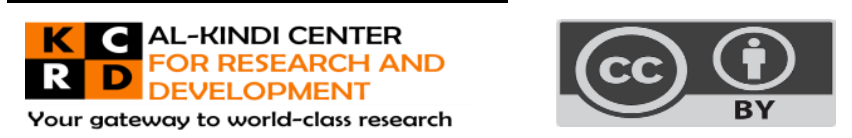

Published by Al-Kindi Center for Research and Development, United Kingdom. Copyright (c) the author(s). This open access article is distributed under a Creative Commons Attribution (CC-BY) 4.0 license

\footnotetext{
2 Undang Undang Dasar Negara Republik Indonesia, Undang Undang Dasar Negara Republik Indonesia (Jakarta: Pemerintah Republik Indonesia, 1945).

${ }^{3}$ Kementerian Kesehatan Republik Indonesia, Peraturan Menteri Kesehatan No 28 Tahun 2011 (Jakarta: Kementerian Kesehatan Republik Indonesia, 2011).
} 
is indicated by the emergence of various public complaints through the mass media. If this condition is not responded to, it will cause a bad image. The measurement of satisfaction is carried out to guarantee the quality that has been provided during the one-year running of the National Health Insurance (JKN) program, both by BPJS as the organizer and by health service facilities as service providers. In general, patient satisfaction measurement serves to measure and see the level of community satisfaction with services. Measuring patient satisfaction is intended to see the picture and develop and improve the quality of service continuously so that good corporate governance can be created ${ }^{4}$.

However, on December 31, 2019, the WHO China Country Office reported pneumonia of unknown etiology in Wuhan City, Hubei Province, China. On January 7, 2020, China identified unknown etiology as a new type of coronavirus (novel coronavirus, 2019$\mathrm{nCoV})$. The increase in 2019- $\mathrm{nCoV}$ cases has been speedy and has spread outside the Wuhan area and other countries $\left({ }^{5}\right.$. As of December 28,2020 , there were at least $79,515,525$ confirmed coronavirus cases, with a death rate of 1,757,947 people in various countries in the world ${ }^{6}$.

Meanwhile, in Indonesia, according to the Ministry of Health of the Republic of Indonesia, since it was first announced that there were two confirmed cases of COVID-19, so far, it has not shown a decrease. The number of coronavirus sufferers reached 719,219 , with a death toll of 21,452 .

According to $(7$, during a pandemic, the health system is faced with maintaining a balance between meeting the needs for handling a pandemic and fulfilling essential health services. This balance must be maintained so that there is no increase in other diseases after the COVID-19 pandemic is over. During the COVID-19 pandemic, the role above is necessary and is the primary key to tackling COVID-19 in Indonesia. From the nature of the service, a family doctor must take preventive measures before disease or complications arise. In addition, education and monitoring are still carried out both for healthy people and people who have been declared sick and also for people who have recovered. They are still given education and are supervised to maintain their best condition ${ }^{8}$.

In addition, the existence of a health protocol must be carried out to break the chain of the spread of COVID-19. It is necessary to make adjustments related to technical health services carried out by the FKTP. This, of course, can affect the quality of service, which can also affect the satisfaction felt by patients.

This study aims to determine the service satisfaction felt by patients during a pandemic at Clinic $X$ in Surabaya. This research is also expected to be used as material for evaluating management processes to increase patient satisfaction at Clinic $X$, especially during the COVID-19 pandemic.

\section{Literature Review}

The definition of customer satisfaction given by Philip Kotler (Kotler et al. 2013) says that it is predetermined by how the customer's expectations are met. Customer satisfaction is directly connected to customers' needs. The degree to which these needs are fulfilled determines the enjoyment in the case of conformity or disappointment from discrepancy (Hill et al. 2007, 31). Satisfaction could also be described as a process that starts with forming customers' expectations and ends with communication of the obtained experience. However, assessing the conducted service is a very subjective thing. Different internal and external factors could significantly impact customers' expectations. The higher the expectations are, the more difficult it is for the company to satisfy customers and fulfil their needs (Zeithaml 2010, 187).

Customer satisfaction is a sophisticated term composed of a huge range of factors (Armstrong 2011, 68). This part defines all these factors which could be reflected in the three main aspects of satisfaction. First of all, trust will be discussed. After that, the next aspect, loyalty, will be considered. Finally, factors influencing satisfaction should be revealed as an assessment by consumers of the parameter depends on other parameters, and only a comprehensive measurement of trust, loyalty and all the factors gives a complete picture of customer satisfaction.

Patient satisfaction is one of the indicators that must be considered necessary for assessing the quality of care in health care facilities. Badri, et al. (2009) views patient satisfaction as the most crucial point of planning, implementing, and evaluating services in meeting patient needs and creating health care standards that are essential to achieve high quality.

\footnotetext{
${ }^{4}$ Peraturan Menteri Pendayagunaan Aparatur Negara dan Reformasi Birokrasi Republik Indonesia No 14, Pedoman Evaluasi Reformasi Birokrasi Instansi Pemerintah (Jakarta: Kementeriani Pendayagunaan Aparatur Negara dan Reformasi Birokrasi Republik Indoneisa, 2014).

${ }^{5}$ Kementerian Kesehatan Republik Indonesia, 2020a)

${ }^{6}$ World Health Organization, "Situation Dashboard," n.d.

${ }^{7}$ Kementerian Kesehatan Republik Indonesia, 2020b)

${ }^{8}$ Retno Asti Werdhani and Margaretta Prasetyani Gieseller, "Peran Dokter Keluarga Pada Masa Pandemi COVID-19: Penanganan Di Indonesia Dan Jerman," J Indon Med Assoc 70, no. 6 (2020): 70.
} 
Singh and Shah (2011) found that patients can have many reasons for choosing certain medical services. The proportion of patients in choosing health services can vary depending on the completeness of the medical services, such as infrastructure consideration of infrastructure, advice from friends and relatives, transportation convenience, availability of specialists, consultants, proximity to homes, and others.

Young et al. (2000), using a database from Veterans Health Administrations of United States collected from 135 hospitals in 1997 , found that demographic characteristics such as age, health status, and race consistently significantly affected satisfaction scores. Among the institutional characteristics, hospital size consistently significantly affected patient satisfaction scores. However, the study was limited to identify patient-level demographic and hospital-level institutional characteristics that may need to be taken into account in comparisons of health care organizations based on patient satisfaction data. The study concludes that hospital managers and clinicians would appear to be in a position to affect patient satisfaction through improvements in service processes.

Other studies indicate that patient satisfaction is positively related to accessibility, availability, and convenience of care (Clearly and McNeil 1988; Weiss and Ramsey, 1989). Strasser (1991) discusses the quantitative measurement of patient satisfaction. It is defined as the measurement of patients' stimuli, value judgments, and reactions to their health care experience through numerical representation. According to Sitzi and Wood (1997), components of satisfaction consist of: structural, technical and interpersonal aspects of care. The structural aspects includes: access, physical setting, costs, convenience, and treatment by non-clinical staff/insurers. The technical aspects include knowledge, competence/quality of care, interventions, and outcomes. The interpersonal aspects include: communication, empathy, and education.

Inui and Carter (1985) highlighted communication between healthcare providers and patients as an extremely important aspect of health care. It is important to augment measures that categorize a specific type of interaction of verbal communication with measures of other types of interaction, such as body language. Effective communication was found to be key to patient satisfaction (Saila et al., 2008). They also found that the most important determinants of an outpatient's opinion of the quality of hospital care were the actual consultation with the doctor.

Douglas et al. (2001) melakukan penelitian dengan judul An empirical investigation of customer satisfaction with health care services dan hasil dari penelitian itu menyebutkan that given an undesirable health outcome, allowing patients a choice of physicians favourably raised patient satisfaction levels.

\section{Methodology}

This study uses an analytic observational approach, namely making direct observations of the variables that are the object of research without giving specific behavior to the object of research ${ }^{9}$. The research design based on the approach used is a crosssectional study because the variables are measured and observed at a certain time and simultaneously ${ }^{10}$.

This study uses a non-probability technique with an incidental sampling method, namely a sample determination technique based on chance, i.e. anyone who accidentally or incidental meets the researcher can be used as a sample if it is considered that the person who happened to be met is suitable as a source of data as many as 200 respondents who are patients. at clinic X and review documents regarding patient satisfaction in the previous year.

Data were collected using a questionnaire to assess patient satisfaction, which consists of reliability, responsiveness, assurance, empathy, and tangible. The questionnaire consists of 22 statements filled in using a Likert scale with a value of 1 to 4 . A score of 1 is given for dissatisfied, 2 for moderately satisfied, 3 for satisfied, and 4 for very satisfied. In 2020, during the COVID-19 pandemic, data collection was carried out using online methods, then compared with patient satisfaction in the previous year using offline techniques. Ethics certificate number 005 / HRECC.FODM / I / 2021.

\footnotetext{
${ }^{9}$ Supriyanto and Djohan, Metodologi Riset Bisnis Dan Kesehatan (Banjarbaru: PT. Grafika Wangi Kalimantan, 2011).

${ }^{10}$ Supriyanto and Djohan.
} 


\section{Results and Discussion}

4.1 Results

Tabel 1. Patient Satisfaction in 2019

\begin{tabular}{|c|c|c|}
\hline \multirow{2}{*}{ Aspect } & \multicolumn{2}{|c|}{ Total } \\
\hline & Score & Average \\
\hline \multicolumn{3}{|l|}{ Reliability } \\
\hline 1. Registration officers are always available at the practice during service hours & 782 & 3,91 \\
\hline 2. Easy patient admission procedure & & \\
\hline 3. The doctor prescribes medical health insurance & 777 & 3,89 \\
\hline 4. Opening hours of family doctors according to schedule & 768 & 3,84 \\
\hline 5. Doctors are always available during service hours & 740 & 3,7 \\
\hline \multirow[t]{2}{*}{ 6. Summons based on the order of arrival } & 753 & 3,77 \\
\hline & 775 & 3,88 \\
\hline The average of reliability aspect & & 3,83 \\
\hline \multicolumn{3}{|l|}{ Assurance } \\
\hline 1. Registration officers provide information that is easy to understand & 771 & 3,77 \\
\hline 2. The doctor provides information that is easy to understand & & \\
\hline \multirow[t]{2}{*}{ 3. The doctor explains the drug given to the patient } & 766 & 3,83 \\
\hline & 754 & 3,86 \\
\hline The average of assurance aspect & & 3,82 \\
\hline \multicolumn{3}{|l|}{ Responsiveness } \\
\hline 1. Registration officers serve patients deftly & 771 & 3,86 \\
\hline 2. The patient's complaint was responded to well & 773 & 3,87 \\
\hline 3. Patient complaints are responded to quickly & 774 & 3,87 \\
\hline The average of responsiveness aspect & & 3,86 \\
\hline \multicolumn{3}{|l|}{ Tangible } \\
\hline 1. Complete facilities for practice & 781 & 3,91 \\
\hline 2. Adequate seating & 769 & 3,85 \\
\hline 3. Cleanliness of the practice place is maintained & 778 & 3,89 \\
\hline $\begin{array}{l}\text { 4. There is a means of information about health insurance in the form of } \\
\text { posters/brochures }\end{array}$ & 754 & 3,77 \\
\hline 5. The location where the practice is easy to reach & 759 & 3,8 \\
\hline The average of tangible aspect & & 3,84 \\
\hline \multicolumn{3}{|l|}{ Empathy } \\
\hline 1. Registration officers do not differentiate between patients & 783 & 3,84 \\
\hline 2. Friendly registration clerk & 768 & 3,92 \\
\hline 3. Doctors spend time listening to patient complaints & 776 & 3,88 \\
\hline 4. Doctors do not discriminate against patients & 778 & 3,89 \\
\hline 5. Doctors are friendly in providing services & 777 & 3,89 \\
\hline The average of empathy aspect & & 3,88 \\
\hline Total Satisfaction & & 3,85 \\
\hline
\end{tabular}

The table above explains that in 2019 of the five aspects assessed, the empathy aspect has the highest value, which is 3.88 , then the responsiveness aspect is 3.86. The tangible aspect has a value of 3.84; reliability has a value of 3.83. Meanwhile, the assurance aspect has the lowest value, namely 3.82. Overall, the total average patient satisfaction in 2019 was 3.85 . At the same time, the target set is 3.60. It can be said that clinic $X$ has had a good score and exceeded the expected target.

Tabel 2. Patient Satisfaction in 2020

\begin{tabular}{crr}
\hline \multicolumn{1}{c}{ Aspect } & \multicolumn{2}{c}{ Total } \\
\cline { 2 - 3 } & \multicolumn{1}{c}{ Score } & Average \\
\hline Reliability & 710 & 3,55 \\
1. Registration officers are always available at the practice during service hours & 720 & 3,60 \\
2. Easy patient admission procedure & 715 & 3,58 \\
3. The doctor prescribes medical health insurance & \\
\hline
\end{tabular}




\begin{tabular}{|c|c|c|c|}
\hline 4. & Opening hours of family doctors according to schedule & 706 & 3,53 \\
\hline 5. & Doctors are always available during service hours & 710 & 3,55 \\
\hline & Summons based on the order of arrival & 719 & 3,60 \\
\hline \multicolumn{3}{|c|}{ The average of reliability aspect } & 3,57 \\
\hline \multicolumn{4}{|c|}{ Assurance } \\
\hline 1. & Registration officers provide information that is easy to understand & 718 & 3,61 \\
\hline 2. & The doctor provides information that is easy to understand & 720 & 3,65 \\
\hline & The doctor explains the drug given to the patient & 724 & 3,59 \\
\hline \multicolumn{3}{|c|}{ The average of assurance aspect } & 3,61 \\
\hline \multicolumn{4}{|c|}{ Responsiveness } \\
\hline 1. & Registration officers serve patients deftly & 724 & 3,62 \\
\hline 2. & The patient's complaint was responded to well & 720 & 3,60 \\
\hline & Patient complaints are responded to quickly & 718 & 3,59 \\
\hline \multicolumn{3}{|c|}{ The average of responsiveness aspect } & 3,6 \\
\hline \multicolumn{4}{|c|}{ Tangible } \\
\hline 1. & Complete facilities for practice & 720 & 3,60 \\
\hline 2. & Adequate seating & 719 & 3,60 \\
\hline 3. & Cleanliness of the practice place is maintained & 722 & 3,61 \\
\hline 4. & $\begin{array}{l}\text { There is a means of information about health insurance in the form of } \\
\text { posters/brochures }\end{array}$ & 698 & 3,49 \\
\hline & The location where the practice is easy to reach & 718 & 3,59 \\
\hline \multicolumn{3}{|c|}{ The average of tangible aspect } & 3,58 \\
\hline \multicolumn{4}{|c|}{ Empathy } \\
\hline & Registration officers do not differentiate between patients & 717 & 3,58 \\
\hline 2. & Friendly registration clerk & 716 & 3,59 \\
\hline 3. & Doctors spend time listening to patient complaints & 731 & 3,66 \\
\hline 4. & Doctors do not discriminate against patients & 727 & 3,64 \\
\hline & Doctors are friendly in providing services & 733 & 3,67 \\
\hline \multicolumn{3}{|c|}{ The average of empathy aspect } & 3,62 \\
\hline \multicolumn{3}{|c|}{ Total } & 3,60 \\
\hline
\end{tabular}

Based on the table above, it can be seen that in 2020, the empathy aspect has the highest value of the other four aspects, namely 3.52. The assurance aspect occupies the position with the second-highest value, namely 3.51. Furthermore, the tangible aspect has a value of 3.48. The responsiveness aspect has a value of 3.47. Meanwhile, the aspect of reliability has a value of 3.46 and occupies the lowest score. If you pay attention to each statement, the lowest score is about the existence of clear information in the form of posters, brochures, or other facilities owned by clinic $X(3.49)$, followed by the doctor's willingness to prescribe medical health insurance (3.53) and continued with the presence of registration officer during service hours (3.55). When viewed as a whole, the total average patient satisfaction at clinic X in 2020 is 3.48 , with the target satisfaction set by clinic $X$, which is 3.8 .

Thus, it can be explained that during the COVID-19 pandemic in 2020, clinic X experienced a significant decrease in customer satisfaction and had not yet been able to reach the predetermined target.

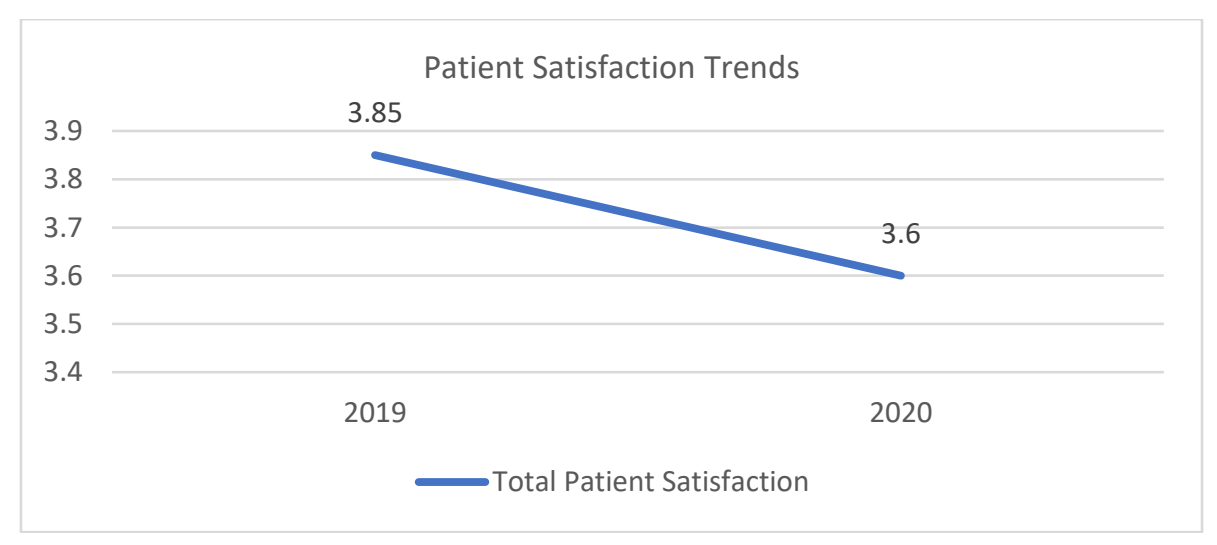

Figure 1. Total Patient Satisfaction in 2019 and 2020 
The picture above shows that there is a downward trend in the overall assessment of patient satisfaction. In 2019, before the COVID-19 pandemic, the patient satisfaction assessment at clinic $X$ reached 3.85. Whereas in the following year or during the COVID-19 pandemic in 2020, the assessment of patient satisfaction decreased to 3.60. Thus, it can be seen that there is a decrease in the assessment of patient satisfaction at clinic X by 0.25 points. In 2019 and 2020, the five aspects assessed have decreased in assessment. Responsiveness, reliability, empathy, and tangible aspects each decreased by 0.26 points. Meanwhile, the assurance aspect decreased the least among other aspects, namely by 0.21 points. This is explained in Figure 2 as follows.

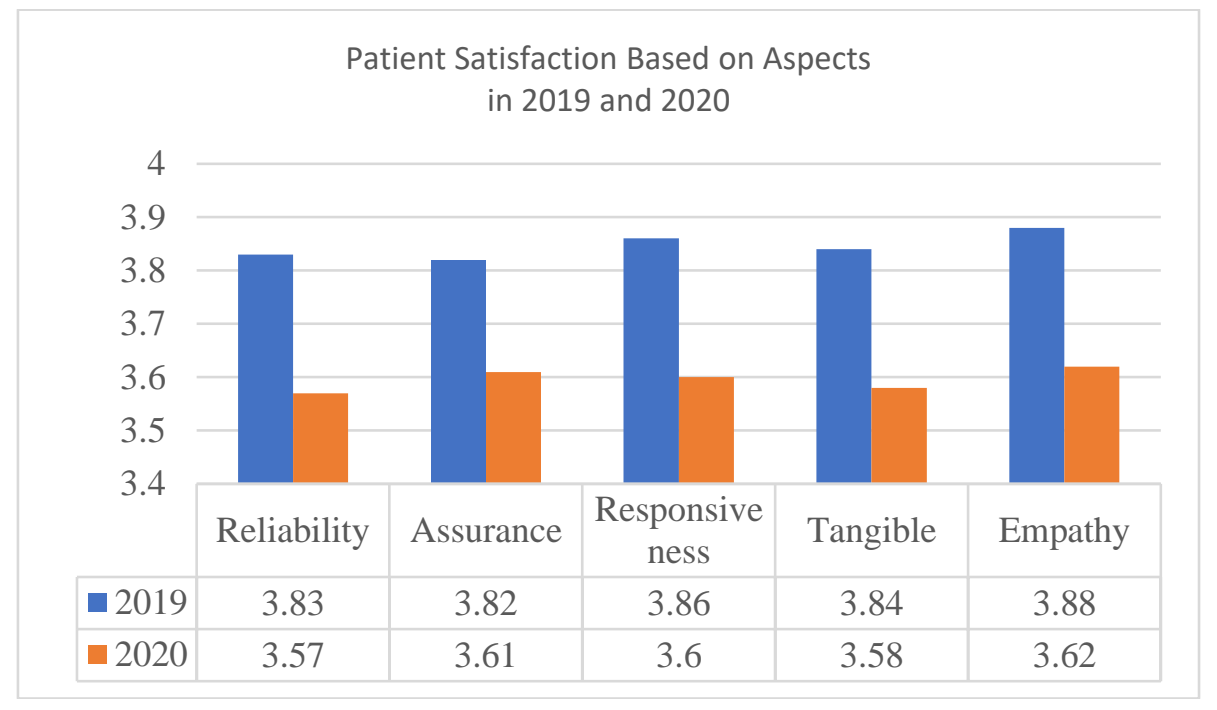

Figure 2. Patient satisfaction based on Reliability, Assurance, Responsiveness, Tangible and Emphaty aspect in 2019 and 2020

\subsection{Discussion}

Several factors influence customer satisfaction. There are five categories: product quality, service quality, price, emotional factors, and cost of acquiring ${ }^{11}$. One of the most well-known service quality approaches is the Servqual (Service Quality) model developed by Parasuraman, Zeithaml, and Berry ${ }^{12}$.

Based on this service quality model, the following five determinants of service quality are identified, based on the order of their importance, consisting of reliability, responsiveness, assurance, empathy, and tangibility.

\subsubsection{Reliability}

Reliability means the organization performs services right the first time. Moreover, it shows that the organization strives to fulfill promises and pay attention to the results (Pakurár et al., 2019). From the survey statements that were distributed, there were six satisfaction statements related to the reliability of the services provided by clinic $X$. including registration officers who are always in the practice place during service hours, easy patient admission procedures. Doctors prescribe medical health insurance, family doctor opening hours according to schedule, doctors always available at service hours, and calls based on the order of arrival. In 2019, the assessment of patient satisfaction on the aspect of reliability reached 3.83. Meanwhile, in 2020 it decreased by 0.39 points to 3.46. In this aspect of reliability, the most significant decrease was in the statement that registration officers were always in practice during service hours. This may be due to changes in service times carried out by clinic X during the COVID-19 pandemic. This change in time may not have been widely known by patients, resulting in decreased satisfaction with statements about registration officers who are always present at the practice.

Before the pandemic, clinic X's service time was available Monday to Friday from 07.30 to 19.30 and Saturday from 07.30 to 16.30 , while during the pandemic, the service time changed to Monday to Friday from 09.00 to 15.00 . This is done by clinic $X$ in order to break the chain of the spread of the coronavirus. However, in exchange for the changes in service time made, clinic $X$ also provides telemedicine services recently launched through the JKN mobile application.

This section is a comparative or descriptive analysis of the study based on the study results, previous literature, etc. The results should be offered in a logical sequence, given the most important findings first and addressing the stated objectives. The author should deal only with new or important aspects of the results obtained. The relevance of the findings in the context of existing literature or contemporary practise should be addressed.

\footnotetext{
11 Supriyanto and Ernawaty, Pemasaran Industri Jasa Kesehatan (Yogyakarta: Penerbit Andi, 2010).

${ }^{12}$ Hamdani Lupiyoadi, Manajemen Pemasaran Jasa., 2nd ed. (Jakarta: Penerbit Salemba Empat, 2006).
} 


\subsubsection{Assurance}

Assurance or assurance is the knowledge and courtesy of employees and their ability to inspire trust and confidence ${ }^{13}$. The assurance aspect in the 2020 satisfaction survey had a minor decrease in assessment compared to other aspects. In the survey, there were three statements related to the guarantee of services provided by clinic $X$, including the registration officer providing easy-to-understand information, the doctor providing easy-to-understand information, and the doctor explaining the drugs given to patients. From the questions related to this guarantee, there was the most significant decrease in assessment in the third statement; namely, the doctor explained the drug given to the patient. In 2019, the statement received a satisfaction score of 3.86 and 3.59 in 2020. This means that it has decreased by 0.27 .

Every person has the right to obtain information about his / her health data, including the actions and treatments that have been or will be received from health workers. Of course, this must receive more attention to fulfill the patient's right to receive health services ${ }^{14}$.

The World Health Organization (WHO) has also stated that rational drug use is when a patient receives the right drug for clinical needs in a dose that meets the need for a sufficient period and at an affordable cost for both individuals and society. This concept applies when the patient first arrives, including the correct dose, the proper method and duration of administration, the correct information by paying attention to affordability, patient compliance, and being aware of side effects. In addition, to improve patient compliance in taking medication, it must be accompanied by the provision of adequate information. In other words, information about drugs is an integral part of the health care process.

Previous research stated that there was an effect of information on a person's adherence to medication adherence so that the provision of information should be given very well, such as in consultation efforts or can also use other means.

\subsubsection{Responsiveness}

Responsiveness is that officers are willing to provide transparent information, pay attention and respond according to customer requests ${ }^{15}$. Based on the survey conducted, three statements related to responsiveness, including registration officers served patients deftly, patient complaints were responded to well, and patient complaints were responded to quickly. The patient's complaint statement was responded to quickly; it was felt that the patient had decreased the most (0.26 points) and had the lowest value among other statements, namely 3.59 in 2020 from 3.86 in 2019.

When a customer makes a complaint, the best thing to do is respond as quickly as possible. Complaints can be accommodated to get a resolution, but prompt handling is the best solution desired by the customer. If this customer complaint is handled slowly, the customer will likely be disappointed with the service provided.

Handling customer complaints can be the most effective way to solve problems before they get worse. In previous research, it was stated that handling complaints is feedback to improve service quality. Complaints that are not responded to will cause considerable losses for service providers in spreading a lousy image to reduce customer trust and create a bad image for the service provider. This is in line with other research that states that underestimating customer complaints can destroy a company's career. The company's image will be destroyed because dissatisfied customers are very likely to share their bad experiences with others ${ }^{16}$.

Responding to complaints quickly does not mean taking action rashly. Rash handling with inappropriate actions can lead to new problems that make it even more complicated ${ }^{17}$.

\subsubsection{Tangible}

Tangible objects are physical facilities (equipment, personnel, and communication materials) that customers will use to assess quality ${ }^{18}$. Of the 22 satisfaction survey statements, there are five statements related to physical aspects, including facilities for complete practice, adequate seating, cleanliness of the practice place, available information on health insurance in the form of posters, brochures, etc. as well as the location where the practice is easy to reach. The first statement on physical facilities, namely

\footnotetext{
${ }^{13}$ A. Parasuraman, Leonard L. Berry, and Valarie A. Zeithaml, "Perceived Service Quality as a Customer-based Performance Measure: An Empirical Examination of Organizational Barriers Using an Extended Service Quality Model," Human Resource Management 30, no. 3 (1991): 335-64, https://doi.org/10.1002/hrm.3930300304.

${ }^{14}$ Undang-Undang Republik Indonesia No 36, Tentang Kesehatan (Jakarta: Pemerintah Republik Indonesia, 2009).

15 Parasuraman, Berry, and Zeithaml, "Perceived Service Quality as a Customer-based Performance Measure: An Empirical Examination of Organizational Barriers Using an Extended Service Quality Model."

${ }^{16}$ Dede Suparyani, "Analisa Penanganan Keluhan Pelaggan Oleh Customer Care Di PT. XYZ" (Skripsi: President University, 2017).

${ }^{17}$ Isma Rachmadhani Putri, "Tinjauan Atas Penanganan Keluhan Pelanggan Pada Pt. Tauba" (Tugas Akhir: Sekolah Tinggi Ilmu Ekonomi Kesatuan Bogor, 2015), https://doi.org/10.13140/RG.2.2.28714.52160.

18 Parasuraman, Berry, and Zeithaml, "Perceived Service Quality as a Customer-based Performance Measure: An Empirical Examination of Organizational Barriers Using an Extended Service Quality Model."
} 
facilities for complete practice, was the statement that had the most reduction, namely 0.31 points. In 2019 , the statement had a value of 3.91 and became 3.60 in 2020.

According to ${ }^{19}$, the physical aspect is positively related to the level of outpatient satisfaction at the Central Lamper Pusksemas. In addition, other studies have found that environmental and infrastructure aspects have a reasonably large portion of service satisfaction ${ }^{20}$. The same thing was also expressed in other studies ${ }^{21}$.

Many adjustments need to be made in implementing services in the current pandemic condition. Suppose you pay attention to the Technical Guidelines for Community Health Center Services during the COVID-19 Pandemic ${ }^{22}$. In that case, FKTP must fulfill many facilities and infrastructure to suppress the spread of the coronavirus, such as the availability of handwashing facilities such as a sink with running water and liquid soap so that Each visitor or patient can wash their hands with soap (CTPS) when they come and go home from the FKTP and ensure adequate air exchange inside and outside the building with ventilation by combining natural and mechanical methods to ensure good air quality, so that droplet concentrations decrease. . the patient may feel this to be incomplete so that there is a decrease in the assessment of patient satisfaction at clinic $\mathrm{X}$.

\subsubsection{Empathy}

Empathy means caring, giving personal attention, and providing service to customers. Customers need to feel that the service provider is making them a priority. The essence of empathy is conveying the feeling that the customer is unique and special, ${ }^{23}$. There are five statements related to empathy, including, registration officers do not differentiate between patients, friendly registration officers, doctors take time to listen to patient complaints, doctors do not differentiate between patients, and doctors are friendly in providing services In 2019, the statement regarding registration officers friendly has a value of 3.84 . However, there was a decrease in the assessment of 0.33 points in 2019 to 3.59. This statement is the statement that has the most significant decline in value among the other four statements.

As the executor of activities and service delivery processes, the friendliness of the officers plays a vital role in determining the level of quality of public services. The friendly attitude of the officers is one of the main aspects that every service provider must-have. Fast, precise, accurate, cheap, and friendly service is the standard of service that can provide excellent service ${ }^{24}$.

A decrease in staff friendliness must be an evaluation point that should be carried out immediately to maintain the clinic order to maintain reasonable customer satisfaction and achieve the desired targets.

Improving the quality of services at first-level health facilities is very ${ }^{25}$. This is due to the critical role of first-level health facilities in health development.

\section{Conclusion}

There was a decrease in customer satisfaction at Clinic X in Surabaya during the COVID-19 pandemic in 2020. An aspect that must be corrected immediately is related to clinic service hours. This has been overcome by carrying out telemedicine innovations. This may be more effective by providing clear information to clinic X's customers by giving leaflets or short messages on social media belonging to clinic $X$. In addition, the friendliness of the officers also needs to be improved considering that this is an aspect of minimum service standards in providing good service. Prime. The availability of facilities and infrastructure in the conditions of the COVID-19 pandemic also urgently needs to be improved to break the chain of disease spread. Speed in responding to customer complaints must also be done immediately to suppress wrong customer opinions.

Funding: "This research received no external funding"

Acknowledgments: I would like to thank you to my husband, my children, and all my friends for the support and assistance they have given to me at the time of writing this article.

Conflicts of Interest: The authors declare no conflict of interest.

\footnotetext{
${ }^{19}$ Defi Mernawati and Intan Zainafree, "Analisis Faktor-Faktor Yang Berhubungan Dengan Tingkat Kepuasan Pasien Rawat Jalan Di Puskesmas Lamper Tengah Kecamatan Semarang Selatan Kota Semarang," Public Health Perspective Journal 1, no. 1 (2016): 45-52.

20 Masood A. Badri, Samaa Attia, and Abdulla M. Ustadi, "Healthcare Quality and Moderators of Patient Satisfaction: Testing for Causality," International Journal of Health Care Quality Assurance 22, no. 4 (2009): 382-410, https://doi.org/10.1108/09526860910964843.

${ }^{21}$ Aditi Naidu, "Factors Affecting Patient Satisfaction and Healthcare Quality," International Journal of Health Care Quality Assurance 22, no. 4 (2009): 366-81, https://doi.org/10.1108/09526860910964834.

22 Kementerian Kesehatan Republik Indonesia, "Petunjuk Pelayanan Puskesmas Pada Masa Pandemi COVID-19," 2020.

${ }^{23}$ Miklós Pakurár et al., "The Service Quality Dimensions That Affect Customer Satisfaction in the Jordanian Banking Sector," Sustainability (Switzerland) 11, no. 4 (2019): 1-24, https://doi.org/10.3390/su11041113.

${ }^{24}$ Sedarmayanti, Sumber Daya Manusia Dan Produktivitas Kerja, Istinbath, vol. 15 (Bandung: Mandar Maju, 2016).

${ }^{25}$ Undang-Undang Republik Indonesia No 36, Tentang Kesehatan.
} 


\section{References}

[1] Badri, Masood A., Samaa Attia, and Abdulla M. Ustadi. (2009). Healthcare Quality and Moderators of Patient Satisfaction: Testing for Causality." International Journal of Health Care Quality Assurance, 22(4), 382-410. https://doi.org/10.1108/09526860910964843.

[2] Kementerian Kesehatan Republik Indonesia. (2020). Pedoman Kesiapsiagaan Menghadapi Infeksi Novel Coronavirus (2019-NCov). 1st ed. Jakarta: Direktorat Jenderal Pencegahan dan Pengendalian Penyakit, 2020.

[3] - Peraturan Menteri Kesehatan No 28 Tahun (2011). Jakarta: Kementerian Kesehatan Republik Indonesia, 2011.

[4] . "Petunjuk Pelayanan Puskesmas Pada Masa Pandemi COVID-19," 2020.

[5] Lupiyoadi, H. (2006). Manajemen Pemasaran Jasa. 2nd ed. Jakarta: Penerbit Salemba Empat,

[6] Mernawati, Defi, and Intan Zainafree. (2016). Analisis Faktor-Faktor Yang Berhubungan Dengan Tingkat Kepuasan Pasien Rawat Jalan Di Puskesmas Lamper Tengah Kecamatan Semarang Selatan Kota Semarang." Public Health Perspective Journal 1(1), 45-52.

[7] Naidu, Aditi. "Factors Affecting Patient Satisfaction and Healthcare Quality." International Journal of Health Care Quality Assurance 22, no. 4 (2009): 366-81. https://doi.org/10.1108/09526860910964834.

[8] Pakurár, Miklós, Hossam Haddad, János Nagy, József Popp, and Judit Oláh. (2019). The Service Quality Dimensions That Affect Customer Satisfaction in the Jordanian Banking Sector." Sustainability (Switzerland), 11(4), 1-24. https://doi.org/10.3390/su11041113.

[9] Parasuraman, A., Leonard L. Berry, and Valarie A. Zeithaml. (1991). Perceived Service Quality as a Customer-based Performance Measure: An Empirical Examination of Organizational Barriers Using an Extended Service Quality Model." Human Resource Management, 30(3), 33564. https://doi.org/10.1002/hrm.3930300304.

[10] Peraturan Menteri Pendayagunaan Aparatur Negara dan Reformasi Birokrasi Republik Indonesia No 14. Pedoman Evaluasi Reformasi Birokrasi Instansi Pemerintah. Jakarta: Kementeriani Pendayagunaan Aparatur Negara dan Reformasi Birokrasi Republik Indoneisa, 2014.

[11] Putri, I. (2015). "Tinjauan Atas Penanganan Keluhan Pelanggan Pada Pt . Tauba." Tugas Akhir: Sekolah Tinggi Ilmu Ekonomi Kesatuan Bogor. https://doi.org/10.13140/RG.2.2.28714.52160.

[12] Sedarmayanti. (2016). Sumber Daya Manusia Dan Produktivitas Kerja. Istinbath. Vol. 15. Bandung: Mandar Maju,

[13] Suparyani, Dede. (2017). Analisa Penanganan Keluhan Pelanggan Oleh Customer Care Di PT. XYZ." Skripsi: President University.

[14] Supriyanto, and Djohan. (2011). Metodologi Riset Bisnis Dan Kesehatan. Banjarbaru: PT. Grafika Wangi Kalimantan.

[15] Supriyanto, and Ernawaty. Pemasaran Industri Jasa Kesehatan. Yogyakarta: Penerbit Andi, 2010.

[16] Undang-Undang Republik Indonesia No 36. (2009). Tentang Kesehatan. Jakarta: Pemerintah Republik Indonesia,

[17] Undang Undang Dasar Negara Republik Indonesia. (1945). Undang Undang Dasar Negara Republik Indonesia. Jakarta: Pemerintah Republik Indonesia

[18] Werdhani, Retno Asti, and Margaretta Prasetyani Gieseller. (2020). Peran Dokter Keluarga Pada Masa Pandemi COVID-19: Penanganan Di Indonesia Dan Jerman." J Indon Med Assoc, 70(6) 70.

[19] World Health Organization. "Situation Dashboard," n.d.

[20] Young, G.J., Meterko, M., \& Desai, K.R. (2000). Patient Satisfaction with Hospital Care: Effects of Demographic and Institutional Characteristics. Medical Care, 38(3), 325-334.

[21] Zineldin, M. (2006). The quality of Healthcare and patient satisfaction. International Journal of Heatlhcare Quality assurance, 19(1), 16-92

[22] Cleary, P.D. \& McNiel, B.J. (1988). Patient Satisfaction as an Indicator of Quality of Care. Inquiry, 25-36.

[23] Singh, R.G., \& Shah, M.K. (2011). Customers' Preference for Selecting Private Hospital: A Study of Manipur. Management Convergence, 2(2), 41-50.

[24] Weiss, G.L., \& Ramsey, C.A. (1989). Regular Source of Primary Medical Care and Patient Satisfaction. Quality Review Bulletin, 180-184

[25] Sitzia, J., \& Wood, N. (1997). Patient Satisfaction: A Review of Issues and Concepts. Social Science and Medicine, 45, 1829-1843.

[26] Kotler, Philip, Bowen, John, Makens, J. (2013). Marketing for hospitality and tourism. Pearson education, Inc. Upper Saddle river.

[27] Zeithaml, V., Bitner, M., Gremler, D. (2010). Services Marketing: Integrating Customer Focus Across the Firm. Boston: McGraw-Hill

[28] Armstrong, Michael 2011. How to be an Even Better Manager: A Complete A-Z of Proven Techniques and Essential Skills. Kogan Page Publishers.

[29] Strasser, S., \& Associates. (1992). Measuring Patient Satisfaction for Improved Patient Service. Ann Arbor, Ml: Health Administration Press

[30] Hill, Nigel, Roche, Greg, Allen, Rachel 2007. Customer Satisfaction: The Customer Experience Through the Customer's Eyes. The Leadership Factor.

[31] Inui, T. \& Carter, W. (1985). Problems and Prospects for Health Services Research on Provider-Patient Communication. Medical Care, 23(5), 521-538.

[32] Saila, T., Mattila, E., Kaila, M., Alto, P., \& Kaunonen, M. (2008). Measuring Patient assessment of quality of outpatient care: a systematic review. Journal of Evaluation in Clinical practice, 14, 148-154.

[33] Amyx, D., \& Bristow, D. N. (2001). An empirical investigation of customer satisfaction with health care services. Marketing Intelligence \& Planning, 19(7), 515-525. 